\section{S0SIAfLL- Lä̈̈HETIETEELLUNELI AIHAHAUSLEHTI}

Journal of Social Medicine

Päätoimittaja

Riikka Lämsä

editor@socialmedicine.fi

Toimitussihteeri

Suvi Määttä

Puh. 0405937048

toimitussihteeri@socialmedicine.fi

Lehden internetsivut

http://journal.fi/sla

Julkaisija

Sosiaalilääketieteen yhdistys ry

Socialmedicinska föreningen of

Julkaisijan osoite

Sosiaaliläketieteen yhdistys

c/o Paula Jäskeläinen

Snellmaninkatu 25 B 19b

00170 Helsinki

Yhdistyksen puheenjohtaja

Peija Haaramo

Terveyden ja hyvinvoinnin laitos

PL 30

0027 I Helsinki

Yhdistyksen jäsensihteeri

Laura Pääkkö

jasensihteeri@socialmedicine.fi

Ilmestymisaikataulu

Neljä numeroa vuodessa (helmikuu, toukokuu, syyskuu ja joulukuu)

Kirjapaino ja taitto

Kirjapaino Hermes Oy

Tämä julkaisu on saanut TSV:n kautta tieteellisen julkaisutoiminnan avustusta, jota opetus- ja kulttuuriministeriö myöntää Veikkauksen tuotoista

ISSN 0355-5097

Kirjapaino Hermes Oy 2019

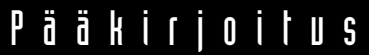

$1 / 2019$

56. VUOSIKERTA

\title{
Toimituksen terveiset
}

Viime vuonna lehdessä juhlittiin Sosiaalilääketieteen yhdistyksen 50 -vuotista taivalta. Se näkyi kirjoituksina, joissa peilattiin yhdistyksen ja lehden historiaa, kuvailtiin yhdistyksen nykytilannetta sekä suunnattiin katsetta tulevaan. Se tuleva on käsillä nyt. Tänä vuonna lehdellä on tarjota sopiva sekoitus uudistuksia, hyviksi todettujen toimintatapojen ylläpitämistä ja perinteiden vaalimista.

Sydämellisesti kiitämme lehden edellistä päätoimittajaa Sari Räisästä, joka uudisti ja vahvisti lehteä ennakkoluulottomasti ja toi sen digiaikaan (esimerkiksi sähköinen arviointijärjestelmä ja vertaisarviointitunnusten hankkiminen). Sarin jalanjäljissä meillä, uudella päätoimittajalla Riikka Lämsällä ja toimitussihteerinä jatkavalla Suvi Määtällä, on helppo tehdä työtämme. Toimituskunta on sekoitus vanhaa ja uutta. Kokeneina toimittajina jatkavat Maijaliisa Erkkola, Hanna Konttinen ja Sakari Suominen. Uusia kasvoja ovat Minna Kaarakainen, Marko Manninen ja Anja Terkamo-Moisio. Toimituskunnasta ylpeinä voimme kertoa, että se edustaa laajasti eri tieteenaloja ja tutkimusmenetelmiä sekä yliopistoja ja tutkimuslaitoksia. Maantieteellisesti toimituskunta voisi olla vieläkin kattavampi.

Lehdessä aloitetaan uusi Tieteestä politiikkaa -puheenvuorojen sarja. Ajatuksena on antaa ääni heille, jotka vievät tieteellisesti tutkittua tietoa poliittiseen valmistelutyöhön ja päätöksentekoon tai käyttävät tutkimustuloksia omassa työssään virkamiehinä ja päättäjinä. Tieteen ja politiikan rajapinnalla liikkuvan kirjoitussarjan tavoitteena on luoda vuoropuhelua ja sitä kautta ehkäistä vastakkainasettelua.

Ensimmäisen Tieteestä politiikkaa -puheenvuoron (s. 53) on tähän lehteen kirjoittanut Pekka Puska, joka kirjoituksessaan kuvaa kuinka monenlaisia tekijöitä poliittisen päätöksenteon 
taustalta löytyy. Tieteen ja tutkimusnäytön rinnalla lobbaus, mainonta ja keskenään kilpailevat ristiriitaiset poliittiset pyrkimykset ovat vaikuttamassa yhteiskunnalliseen päätöksentekoon. Lehden toinen tämänvuotinen teema on ilmasto, ja loppuvuodesta julkaistaan ajankohtainen ilmastoaiheinen teemanumero. Kirjoituskutsu löytyy alapuolelta.

Sosiaalilääketieteellisen aikakauslehden tavoitteena on palvella perinteisen paperilehden lukijoita mutta myös yhä laajenevaa joukkoa, jotka haluavat lukea lehtensä sähköisessä muodossa. Viime vuonna sähköisessä Journal.fi-järjestelmässä olevien lehtien sisällysluetteloita tarkasteltiin yhteensä 19559 kertaa. Sähköisen julkaisemisen myötä toivomme, että koko lehti tai sen yksittäiset artikkelit löytävät yhä useamman lukijan. Tätä edesauttaa myös aktiivisuus sosiaalisessa mediassa. Tämän vuoden tavoitteena onkin artikkeleiden näkyvyyden ja sosiaalilääketieteellisen keskustelun lisääminen sosiaalisen median eri kanavissa. Tästä hyötyvät sekä kirjoittajat että lehti. Näkyvyyden lisäämisessä hyödynnämme kirjoittajien kokoamia ydinasioita. Vertaisarvioitujen artikkelien ydinasioihin kootaan tiiviisti ja selkeästi keskeiset tulokset ja niiden merkitys, joten niitä on helppo hyödyntää viestinnässä. Ydinasiat näkyvät myös ulkoasuuudistuksena paperisessa lehdessä.

Lehti tarvitsee tekijöitä, kirjoittajia ja lukijoita. Me toimituksessa teemme parhaamme, jotta lehti olisi kiinnostava, ajankohtainen ja tieteellisesti tasokas. Tähän tarvitsemme kirjoittajia, jotka haluavat tuoda esiin tutkimustuloksiaan tai keskustella sosiaalilääketieteellisistä aiheista kotimaisilla kielillä. Loppujen lopuksi lukija on se, jota varten ja jonka ansiosta lehti elää.

\section{RIIKKA LÄMSÄ}

Päätoimittaja

Suvi MäÄTtä

toimitussibteeri

\section{KIRJOITUSKUTSU}

\section{SLA teemanumero: Ilmastokriisi}

Minkälaisia muutoksia ilmaston lämpeneminen tuo ihmisten hyvinvointiin, terveyteen tai vaikkapa sairauksien esiintyvyyteen? Minkälaisia ratkaisuja voisimme tehdä terveyden edistämisessä, terveyskäyttäytymisessä, sosiaali- ja terveydenhuollossa tai -politiikassa ilmastonmuutoksen hillitsemiseksi? Mitä ilmastonmuutos merkitsee globaalin terveyden näkökulmasta?

Sosiaalilääketieteellinen aikakauslehti julkaisee teemanumeron ilmaston lämpenemisestä ja sen merkityksestä sosiaalilääketieteelle. Kutsumme aihepiiristä kiinnostuneita tutkijoita ja tutkijaryhmiä kirjoittamaan teemanumeroon vertaisarvioitavia, empiirisiä tai teoreettisia, tutkimusartikkeleita tai puheenvuoroja.

Lähetä enintään 250 sanan abstrakti kirjoituksesta osoitteeseen editor@socialmedicine.fi viimeistään 28.2.2019. Teemanumeroon liittyvät mahdolliset kysymykset voi osoittaa myös samaan osoitteeseen.

Aiheesta järjestetään mahdollisesti myös Sosiaalilääketieteellisen yhdistyksen teemaseminaari vuonna 2019. 